Ekuitas: Jurnal Pendidikan Ekonomi

Volume 9, Number 1, Tahun 2021, pp. 137-145

P-ISSN : 2354-6107E-ISSN : 2549-2292

DOI : $10.23887 /$ ekuitas.v9i1.34110

Open Access: https://ejournal.undiksha.ac.id/index.php/EKU

\title{
The Influence of the Covid-19 Pandemic on the Financial Performance of Construction SOEs Listed on the Indonesia Stock Exchange
}

\author{
Alvia Herna Tertia ${ }^{*}$, Waspodo Tjipto Subroto ${ }^{2}$ \\ 1,2,Universitas Negeri Surabaya, Surabaya - Indonesia
}

\section{A R T I C L EI N F O}

Article history:

Received April, 282021

Received in revised form May, 212021

Accepted May, 272021

Available online June, 28 2021

Kata Kunci:

BUMN konstruksi, covid-19,

kinerja keuangan.

Keywords:

Construstion state own

enterprise, covid -19,

financial performance.

\begin{abstract}
A B S T R A K
Penelitian ini bertujuan untuk mengetahui pengaruh Pandemi Covid -19 terhadap kinerja keuangan perusahaan BUMN bidang Konstruksi yang terdaftar di Bursa Efek Indonesia periode kuartalan tahun 2016-2020 dan perkembangannya berdasarkan penilaian yang terdapat di Surat Keputusan Menteri Badan Usaha Milik Negara Nomor: KEP100/MBU/2002. Penelitian ini menggunakan teknis analisis trend. Dalam penelitian ini populasi yang digukankan adalah perusahaan BUMN bidang konstruksi yang terdaftar di Bursa Efek Indonesia periode kuartalan tahun 2016-2020 terdapat 4 perusahaan. Teknik pengumpulan data yang digunakan adalah dokumentasi berupa laporan keuangan perusahaan tahun 2016-2020 dan menggunakan teknik evaluasi. Hasil penelitian berdasarkan analisis trend menunjukkan bahwa adanya pengaruh pandemi Covid-19 terhadap kinerja keuangan BUMN bidang Konstruksi, berupa menurunnya kinerja keuangan perusahaan.
\end{abstract}

\section{A B S T R A C T}

This study aims to determine the effect of the Covid-19 Pandemic on the financial performance of BUMN companies in the construction sector listed on the Indonesia Stock Exchange for the 2016-2020 quarterly period and its development based on the assessment contained in the Decree of the Minister of StateOwned Enterprises Number: KEP-100 / MBU. / 2002. This study uses technical trend analysis. In this study, the population used is a state-owned company in the construction sector listed on the Indonesia Stock Exchange for the 2016-2020 quarterly period. There are four companies. The data collection technique used is documentation in the form of company financial reports for 2016-2020 and uses evaluation techniques based on the Decree of the Minister of State-Owned Enterprises Number: KEP-100 / MBU / 2002. The study results based on trend analysis indicate that the Covid-19 pandemic influences the financial performance of BUMN in the construction sector in the form of a decrease in the company's financial performance.

\footnotetext{
* Corresponding author.

E-mail :alvia.17080554075@mhs.unesa.ac.id(AlviaHerna Tertia)
} 


\section{Preliminary}

The continuous infrastructure development in Indonesia is one factor in the increasing role of the construction sector in the Indonesian economy. This can be seen from the large percentage of the construction sector to Indonesia's Gross Domestic Product (GDP) of 11.11\% in the third quarter of 2019.

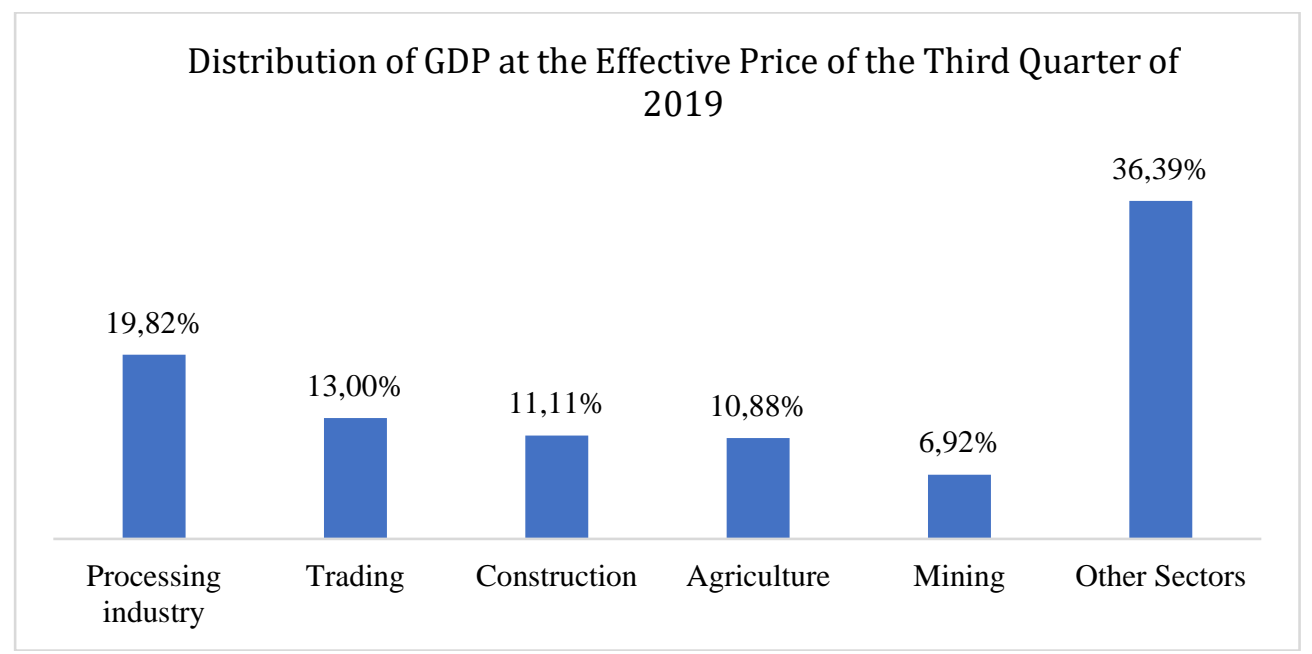

Figure I.Distribution of GDP at the Effective Price of the Third Quarter of 2019 Source: Badan Pusat Statistik

According to the construction sector's role, it can see from the absorption of labour, investment, the number of infrastructure and building projects, reciprocal relationships with supporting sectors, and even being a facilitator in the movement and growth of goods and services.

State-owned enterprises (BUMN) are government-owned companies or organizations tasked with regulating and managing Indonesia's natural resources related to the interests and welfare of the Indonesian people. According to data from REGULATION OF THE MINISTER OF STATE-OWNED BUSINESS AGENCIES OF THE REPUBLIC OF INDONESIA NUMBER: PER - 8 / MBU / 08/2020 Indonesian BUMN, as of August 2020, there are 107 BUMN companies in Indonesia which divide into 12 clusters. In this cluster, there are 4 (four) state-owned construction companies that have gone public, including PT. Wijaya Karya (Persero) Tbk, PT. Waskita Karya (Persero) Tbk, PT. Housing Development (Persero) Tbk, and PT. Adhi Karya (Persero) Tbk. Of course, this state-owned company in the construction sector listed on the Indonesia Stock Exchange needs to control and monitor company performance which can see from the analysis and interpretation of financial data from listed companies as reflected in their financial statements. In increasing the existence of BUMN in the construction sector amid intense competition, state-owned construction companies expect to maintain their quality because the quality of construction companies is the leading guide that must consider in maintaining public trust as users of public facilities. According to \{Formatting Citation\}The only system that can use in calculating the health of a company is through a company performance analysis which aims to see whether the company has implemented the appropriate financial regulations or not. Meanwhile, according to (Sanjaya \& Rizky, 2018)One of the indicators of company quality can be seen from the level of financial performance, because this is a factor used as an assessment to see the health condition of the company for a period in the future. According to (FAKIH, 2019) In assessing the company's financial performance to assess the financial condition of a company, investors and interested parties can use several financial ratios in financial reports, such as calculating profitability ratios, liquidity, activity ratios, and solvency ratios. The results of the financial performance appraisal report for state-owned enterprises in the construction sector can explain the company's condition and assess its health level by using the regulations set by the Ministry of BUMN. This is useful for investors and interested parties. According to the construction sector's role, it can see from the absorption of labour, investment, the number of infrastructure and building projects, reciprocal relationships with supporting sectors, and even being a facilitator in the movement and growth of goods and services.

Entering the beginning of 2020, the world was shocked by the outbreak of a virus called Novel Corona Virus 19, where on March 11, 2020, the World Health Organization (WHO) has officially declared 
that the Corona Virus or covid -19 is a global pandemic originating from the city of Wuhan, China. WHO also explained that the world must be alert not only to the spread of the virus but also to the impact on the country's economy, including Indonesia. Suppressing the spread of the coronavirus, the government, for the first time, implemented Large-Scale Social Restrictions (PSBB) starting in March 2020 to break the chain of the spread of the Corona Virus. According to (Nasruddin \& Haq, 2020) ,PSBB can help prevent the spread of the coronavirus to an area so that people in that area expect to avoid the Corona outbreak. Based on government regulations regarding social distancing and physical distancing, it impacts the economic system in Indonesia because restrictions impose on the mobility of people and goods. Based on information obtained from the Indonesia Stock Exchange (IDX), four construction BUMNs list as having problems with the company's performance during the period. The pandemic is underway. According to data from the Request for Explanation Regarding the Impact of Covid 19, PT Wijaya Karya (Persero) Tbk reported to the IDX that until April, the impact of the Covid-19 pandemic had caused $13 \%$ of the total 208 projects to be delayed, meanwhile $23 \%$ of projects had to be temporarily postponed. As well as a reduction in the number of workers due to the implementation of social and physical distancing. Meanwhile, according to the data, request an explanation regarding the impact of Covid 19 on PT. Adhi Karya (Persero) Tbk. They state that as long as the operational limitation that occurs for one month to three months results in an impact on the project contribution of $25 \%$ of total revenue. This operational limitation affects the company's ability to pay the short-term principal debt of IDR 4 trillion. Meanwhile, according to the data, request an explanation regarding the impact of Covid 19 at PT. Waskita Karya (Persero) Tbk has estimated that the impact of operating restrictions for one month to three months will erode profits by $75 \%$ due to a decrease in income by $25 \%$ to $50 \%$. Not much different from other construction service companies, namely PT. Pembangunan Perumahan (Persero) Tbk. According to the Data Request for Explanation Regarding the Impact of Covid 19, the impact of the pandemic has caused $12 \%$ of projects to be temporarily suspended due to Large-Scale Social Restrictions (PSBB).

This study aims to determine the effect of the Covid-19 Pandemic on the financial performance of BUMN companies in the construction sector listed on the Indonesia Stock Exchange for the 2016-2020 quarterly period and its development based on the assessment contained in the Decree of the Minister of State-Owned Enterprises Number: KEP-100 / MBU. / 2002.

\section{Role of BUMN}

According to (Sumiyati, 2013)the role of BUMN in producing high-quality goods and services at prices that all people can reach and able to compete in global business competition and is expected to provide significant benefits to society through management and supervision. In addition to that, the objectives of BUMNFrom an economic point of view, namely in order to use as national income and so that other business sectors can be managed by the government itself, while from a social perspective, namely to expand employment and become parties that can improve the country's economy.

SOE Health Level Assessment

According to(Nasution \& Sari, 2016), one of the things that need to consider when competing with other state-owned companies is health, which can encourage companies to increase efficiency and competitiveness. According to (Saputro, 2015) ,the assessment of the level of health is one of the ways carried out by the company's financial managers to find out the company's performance in each division that has been given the rights and responsibilities in determining a new procedure in order to achieve better results than the previous period.

\section{Definition of Evaluation}

In this study, using a discrepancy evaluation model, according to (Muryadi, 2017), the evaluation of the gap model is an evaluation model that carries out by assessing the level of suitability of the standards that have been set. In this research, the standard used is in the form of health indicators for BUMN companies which contain in the Decree of the Minister of BUMN Number: KEP-100 / MBU / 2002 concerning the Health Level Assessment of State-Owned Enterprises (BUMN) with the results of the company's financial performance program that each has implemented. Each BUMN Construction company, especially during a specific period.

\section{Definition of Financial Performance}

Financial performance is an analysis tool carried out to determine the extent to which the company has carried out operational activities by established accounting principles(Susilo, 2014). According to (Hindrayani, 2017)the company's financial performance can improve through profitable investments. Companies will get additional funds quickly and cheaply when they have good prospects in the future. 


\section{Purpose of Financial Statement Analysis}

According to the objectives (Maith, 2013)the results of the analysis of financial statements help provide information related to the financial position and conditions of the company that are favorable or detrimental; by knowing the conditions of the company that are losing money, the management will try to improve and prevent losses that occur and can maintain the company's strength, which can use as capital at a later date.

\section{Definition of Financial Ratios}

Financial ratios the most frequently use financial analysis tool; financial ratios link the various estimates contained in financial statements so that the financial condition and results of a company's operations can be interpreted (Gunawan Ade, Wahyuni, 2013). Every state-owned company that has gone public is required to include ratio finance according to the Decree of the Minister of State-Owned Enterprises No: KEP -100 / MBU / 2002. Assessment of financial ratios aims to compare the return and risk relationships of companies of different sizes. Ratios can also show the company profile, economic characteristics, competitive strategies, and financial and investment operations characteristics.

\section{Types of Financial Ratios}

1) Liquidity Ratio

According to (Yusra, 2016)the Liquidity Ratio is a ratio to measure the ability to meet short-term obligations when collected by a company. This ratio is important because failure to pay debts will result in company bankruptcy.

2) Activity Ratio

The activity ratio describes the relationship between the company's operations and the assets needed to support these operations (Ulupui, 2007). Activity ratios can use to estimate the capital required by a company.

3) Solvency Ratio

The ratio used to measure the company's ability to meet short-term and long-term obligations. According to (Suryantini, 2016) the higher the company's solvency, the more outstanding the debt obtained to finance the company's assets and the greater the risk the company gets. The lower the solvency of the company, the better the company's status

4) Profitability Ratio

This ratio measures the company's ability to generate profits on sales, assets and capital during a specific period. This ratio used to evaluate the profit margin of operating activities carried out by the company. According to (Thrisye \& Simu, 2013) ,the profitability ratio is the final result of several policies and decisions made by companies that show the combined effects of liquidity, asset management, and debt effects on the operation results.

\section{The Covid -19 pandemic}

On March 11, 2020, the World Health Organization (WHO) officially declared the Corona Virus or Covid -19 a global pandemic originating from Wuhan, China. The virus, which is spread through droplets of someone who sneezes, coughs, talks, and breathes, then spreads through the air to become small particles in a close distance which people around them can accidentally inhale the air. The Coronavirus, or what often referred to as Covid-19, is a new type of virus currently sweeping worldwide. This virus disaster has caused unrest in people worldwide, one of which is in Indonesia; the government has decided to eliminate the chain of transmission of the covid-19 virus by implementing social distancing and physical distancing. According to (Ristyawati, 2020)activities carried out daily; this is because each individual is prohibited from having direct physical interaction with each individual, so all activities must carry out remotely to prevent the spread of the Covid-19 virus.

Based on the government's decree on Large-Scale Social Restrictions (PSBB), it impacts the economic system in Indonesia because most state-owned and private-owned companies apply the concept of Work For Home (WFH). (Pradiva et al., 2021)All workers or employees can work from home is a Work For a Home concept that every company currently implements. The Ministry of BUMN, as an institution in charge of corporate companies in strategic fields through the Minister of BUMN, Mr Erick Thohir, urges its employees to work from home by sharing official schedules for building management employees, leadership secretaries and related services. This is not easy to apply, especially to construction SOEs or Karya BUMNs, most of which have to work directly in the field and interact physically to ensure the sustainability of state infrastructure development projects. 


\section{Trend Analysis}

According to (Veno, 2016)a Trend Analysis is a statistical analysis that predicts a possibility in the future. According to (Indrawati, 2017) ,the use of trend analysis in company financial performance compares financial ratios from year to year. Therefore, it can see that the development of the company's financial performance. This research will use trend analysis on every financial indicator of BUMN companies in the construction sector listed on the Indonesia Stock Exchange before and after the Covid 19 pandemic.

\section{Methods}

This research conducted at state-owned construction companies that have been listed on the Indonesia Stock Exchange, consisting of PT. Wijaya Karya (Persero) Tbk., PT. Waskita Karya (Persero) Tbk., PT.Pembangunan Perumahan (Persero) Tbk., PT.Adhi Karya (Persero) Tbk. In this study, the sample determine by the purposive sampling method; namely, the sample was determined based on specific considerations according to the research objectives. In this study, the considerations used are:

a) BUMN companies registered on the IDX as issuers during the 2016 to 2020 period

b) BUMN companies that are included in construction companies on the IDX during the period 2016 to 2020

c) Companies that have published annual financial reports from 31 December 2016 to 31 December 2020

In this research, the data collection technique used the documentation method, which means that the data obtained from books, newspapers, magazines, transcripts, meeting minutes, etc. The documents needed in this research are the annual financial statements of construction BUMN companies listed on the Indonesia Stock Exchange (IDX) for the 2016-2020 period.

The data analysis technique in this research based on the Decree of the Minister of BUMN Number: KEP-100 / MBU / 2002, which seen from its financial aspects based on trend analysis techniques.Financial performance assessment techniques based on the Decree of the Minister of BUMN Number: KEP-100 / MBU / 2002.

There are eight indicators to assess the financial performance of state-owned construction companies before and after the impact of the Covid 19 pandemic, consisting of current ratio, cash ratio, collection period, inventory turnover, total asset turnover, total equity, ROA, ROI. The ratio calculation results are assessed by the company's health indicators before and after the influence of the Covid 19 pandemic so that it can see whether the company is healthy, unhealthy, unhealthy during the Covid 19 pandemic.

\section{Results and Discussion}

\section{Financial Performance of PT. Wijaya Karya (Persero) Tbk.}

Based on the results of the analysis that has been processed, it can be seen that the health level of PT Wijaya Karya (Persero) Tbk in 2016-2017 is unstable, this happened in 2016 in the first quarter showing the predicate Unhealthy in the BBB category, the second quarter shows the predicate Healthy category A, the third quarter shows the predicate Unhealthy in the BBB category and the third quarter shows the predicate Healthy category A and in 2017 in the first quarter it shows the predicate Healthy category $A$, the second quarter shows the predicate Healthy category A, the third quarter shows the predicate Unhealthy category BBB and quarter four indicates the predicate Healthy category A. PT. Wijaya Karya (Persero) Tbk was unstable in 2016-2017 with an accumulated value of 42.15 and a total score of $60.21 \%$ in the first quarter. The accumulated value was 48.75 , and the total score was $69.64 \%$ in the second quarter. The accumulated value is 45.15 , and the total score is $64.50 \%$ in the third quarter. The accumulated value was 50.90 , and the total score was $72.71 \%$ in the fourth quarter. In 2017 , in the first quarter, the accumulated value was 50.90 , and the total score was $72.71 \%$. The accumulated value was 49.40, and the total score was $70.57 \%$ in the second quarter. The accumulated value is 45.15 , and the total score is $64.50 \%$. The accumulated value was 48.15 , and the total score was $68.79 \%$. In the 2018-2019 period, the health level of PT. Wijaya Karya tends to be stable, and this happened in 2018 in the first quarter showing the predicate of Unhealthy with the BBB category. In the second quarter, it categorizes as Healthy with category A. In the third quarter, it showed the predicate Healthy with category A. In the 
fourth quarter, it shows the predicate Healthy with category A. Likewise in 2019 in the first quarter it shows the predicate Unhealthy with the BBB category, in the second quarter it shows the predicate Healthy with category A, in the third quarter it shows the predicate Healthy with category A, and in the fourth quarter it shows the predicate Healthy with category A predicate Healthy with category A. PT. Wijaya Karya (Persero) Tbk tends to be stable in 2018-2019 by getting an accumulated value of 42.65 and a total score of $60.93 \%$ in the first quarter. The accumulated value was 47.65 , and the total score was $68.07 \%$ in the second quarter. The accumulated value was 46.75 , and the total score was $66.79 \%$ in the third quarter. The accumulated value was 51.65 , and the total score was $73.79 \%$ in the fourth quarter. Moreover, in 2019 it received an accumulated value of 43.65 and a total score of $62.36 \%$ in the first quarter. The accumulated value was 50.30 , and the total score was $71.86 \%$ in the second quarter. The accumulated value is 50.15 , and the total score is 71.64 in the third quarter. The accumulated value is 53.15 , and the total score is $75.93 \%$ in the fourth quarter.

Entering the beginning of 2020, the health level of PT Wijaya Karya (Persero) has decreased significantly due to the impact of the Covid pandemic. In 2020 in the first quarter, it showed the predicate Unhealthy with the BB category, in the second quarter, it showed the predicate Unhealthy with the BB category, in the third quarter, it showed the predicate Unhealthy with the BB category, until the fourth quarter it showed the predicate Unhealthy with the BB category. In 2020 the accumulated value obtained in the first quarter was 33.55 and a total score of $47.93 \%$, in the second quarter an accumulated value of 31.85 and a total score of $45.50 \%$, in the third quarter an accumulated value of $28.25 \%$ and a total score of $40.36 \%$, and in the fourth quarter an accumulated value of $29.85 \%$ and a total score of $42.64 \%$.

\section{Financial Performance of PT. WaskitaKarya (Persero) Tbk.}

Based on the analysis that has been processed, it can see that the health level of PT. Waskita Karya (Persero) Tbk in 2016-2017 had a different level of health. In 2016 in the first quarter, it received the title of Unhealthy category of BBB; in the second quarter, it received the title of Healthy category A, the third quarter received the title of Healthy category A, and in the fourth quarter, it received the title of Healthy category A. In 2017 it had a stable level of health; quarter one shows the predicate Healthy category A until the fourth quarter-the accumulated value obtained by PT. Wakita Karya (Persero) Tbk in 2016 in the first quarter obtained an accumulated value of 39.55 and a total score of $56.50 \%$, in the second quarter an accumulated value of 50.15 and a total score of $71.64 \%$, in the third quarter an accumulated value of 49.05 and a total score of $70.07 \%$, and in the fourth quarter an accumulated value of 48.05 and a total score of $68.64 \%$. In 2017 in the first quarter, there was an accumulated value of 46.65 and a total score of $66.64 \%$, in the second quarter an accumulated value of 53.65 and a total score of $76.64 \%$, in the third quarter, an accumulated value of 50.40 and a total score of $72.00 \%$, and in the fourth quarter an accumulated score of 49.40 and a total score of $70.57 \%$. In the $2018-2019$ period, the health level of PT. Waskita Karya (Persero) Tbk experienced a good and stable health condition in 2018 in each quarter, namely getting the title Healthy with category A from the first quarter to the fourth quarter, while in 2019 PT. Waskita Karya (Persero) Tbk has also experienced a steady decline in each quarter, namely getting the Unhealthy title in the BBB category. The accumulated value in 2018 in the first quarter obtained a value of 49.40 and a total score of $70.57 \%$, in the second quarter an accumulated value of 53.40 and a total score of $76.29 \%$, in the third quarter an accumulated value of 49.80 and a total score of $71.14 \%$, in the fourth quarter an accumulated score of 50.50 and a total score of $72.00 \%$. In 2019 in the first quarter, there was an accumulated value of 44.30 and a total score of $63.29 \%$, in the second quarter, an accumulated value of 36.80 and a total score of $52.57 \%$, in the third quarter, an accumulated value of 33.30 and a total score of $47.57 \%$, and in the fourth quarter an accumulated score of 33.30 and a total score of $45.57 \%$.

For PT. WaskitaKarya (Persero) Tbk, at the beginning of 2020, the health level of PT. WaskitaKarya (Persero) Tbk experienced a slower decline compared to the previous year, and this was due to the impact of the Covid 19 Pandemic, which limited economic activity around the world. In the first quarter, it shows the predicate Unhealthy category B with an accumulated value of 26.70 and a total score of $38.14 \%$, in the second quarter, it shows the predicate Unhealthy category B with an accumulated value of 23.70 and a total score of $33.86 \%$, in the second quarter. Three shows the predicate Unhealthy category B with an accumulated value of 23.20 and a total score of $33.14 \%$, and in the fourth quarter, it shows the predicate Unhealthy category B with an accumulated value of 27.20 and a total score of $38.86 \%$.

\section{Financial Performance of PT. Pembangunan Perumahan (Persero) Tbk.}

Based on the results of the processed analysis, it can see that the health level of PT. Pembangunan Perumahan (Persero) Tbk in the 2016-2017 quarterly period has a fluctuating health level. In 2016 in the first to fourth quarters, it received the title of Healthy category A. While in 2017 it experienced a decline which occurred in the first quarter it received the title of Unhealthy in the BBB category, then increased 
again in the second quarter with the title Healthy category A, in the third quarter it received the title Healthy AAA category and in the fourth quarter received the title Healthy category A. The accumulated value and a total score obtained by PT. Pembangunan Perumahan (Persero) Tbk in 2016 in the first quarter obtained an accumulation value of 48.15 and a total score of $68.79 \%$ in the first quarter. Two obtained an accumulated value of 54.25 and a total score of $77.50 \%$, in the third quarter an accumulated value of 54.25 and a total score of 77.50 and in the fourth quarter an accumulated value of 55.40 and a total score of 79.14\%. In 2017 in the first quarter, it received an accumulated value of 44.90 and a total score of $64.14 \%$, in the second quarter an accumulated value of 54.40 and a total score of $77.71 \%$, in the third quarter an accumulated value of 56.90 and a total score of $81.29 \%$, in the fourth quarter an accumulated value of 55.40 and a total score of 79.14\%. In the 2018-2019 quarterly period, the health level of PT. Pembangunan Perumahan (Persero) Tbk experienced unstable health. In 2018 in the first quarter, it was categorized as Unhealthy with the BBB category, in the second quarter, it categorized as Healthy with category A, in the third quarter, it categorized as Healthy with category A, and in the fourth quarter, it was predicate as Healthy with category A. Meanwhile, in 2019 the level of health has decreased from the first to fourth quarters. In the first quarter, it has the predicate of Unhealthy with the BBB category, in the second quarter, it has the predicate of Unhealthy with the BBB category, in the third quarter, it has the predicate of Unhealthy with the BBB category and in the fourth quarter it has the predicate of Unhealthy with the BBB category. The accumulated value and a total score obtained by PT. Pembangunan Perumahan (Persero) Tbk in 2018 in the first quarter obtained an accumulated value of 40.70 and a total score of $58.14 \%$, in the second quarter an accumulated value of 47.40 and a total score of $67,71 \%$, in the third quarter an accumulated value of 48.55 and a total score of $69.36 \%$ and in the fourth quarter an accumulated value of 49.65 and a total score of $70.93 \%$. Whereas in 2019 in the first quarter there was an accumulated value of 35.95 and a total score of $51.36 \%$, in the second quarter an accumulated value of 38.05 and a total score of $54.36 \%$, in the third quarter an accumulated value of 38.05 and a total score of $54.36 \%$ and in the fourth quarter an accumulated score of 41.65 and a total score of $59.50 \%$.

For PT. Pembangunan Perumahan (Persero) Tbk, at the beginning of 2020 the health level of PT. Pembangunan Perumahan (Persero) Tbk has decreased which is lower than the previous year. This is due to the impact of the Covid 19 Pandemic, which has limited economic activity around the world. In the first quarter, it shows the predicate Unhealthy with category B with an accumulated value of 26.75 and a total score of $38.21 \%$, in the second quarter, it shows the predicate Unhealthy with category B with an accumulated value of 26.25 and a total score of $37.50 \%$, in the third quarter it shows the predicate Unhealthy with category B with an accumulated value of 24.15 and a total score of $34.50 \%$. In the fourth quarter, a slight improvement or recovery is better than the previous quarter with the BB category with an accumulated value of 30.35 and a total score of $43.36 \%$. This shows that the company can survive during a weakening economic condition due to the impact of the Covid 19 Pandemic even though it has not yet reached its maximum value.

\section{Financial Performance of PT. Adhi Karya (Persero) Tbk.}

Based on the analysis that has been processed, it can see that the health level of PT. Adhi Karya (Persero) Tbk in the 2016-2017 quarterly period had an unhealthy level of health with different categories in each quarter. In 2016 in the first quarter, it categorized as Unhealthy with the BB category, in the second quarter, it categorized as Unhealthy with the BBB category, in the third quarter, it was predicate Unhealthy with the BBB category, in the fourth quarter it was predicate Unhealthy with the BBB category. In 2016; 2017, health was the same as the Unhealthy predicate and the BBB category from the first to fourth quarters. The accumulated value and total score obtained by PT Adhi Karya (Persero) Tbk in 2016 in the first quarter obtained an accumulated value of 33.55 and a total score of $47.93 \%$, in the second quarter, an accumulated value of 35.05 and a total score of $50,07 \%$, in the third quarter an accumulated value of 37.15 and a total score of $53.07 \%$ and in the fourth quarter an accumulated value of 41.15 and a total score of 58.79\%. In 2017 in the first quarter, there was an accumulated value of 36.65 and a total score of $50.93 \%$, in the second quarter an accumulated value of 39.15 and a total score of $55.93 \%$, in the third quarter an accumulated value of 40.65 and a total a score of $58.07 \%$ and in the fourth quarter an accumulated value of 44.40 and a total score of $63.43 \%$. In the 2018-2020 quarterly period, PT Adhi Karya (Persero) Tbk has a low level of health. In 2018 in the first quarter, it was predicate Unhealthy, and the BBB category was up to the third quarter, while in the fourth quarter, there was an increase in the level of health with the predicate Healthy and category A. However, in 2019 it experienced another decline in the first to fourth quarters. In the first quarter, it has an Unhealthy predicate with the BB category, in the second quarter, it has an Unhealthy predicate with the BBB category, in the third quarter, it has an Unhealthy predicate with the BBB category, and in the fourth quarter, it has an Unhealthy predicate with 
the BBB category. The accumulated value and total score obtained by PT Adhi Karya (Persero) Tbk in 2018 in the first quarter obtained an accumulated value of 39.15 and a total score of 55.93\%, in the second quarter, an accumulated value of 39.15 and a total score of 55, 93\%, in the third quarter an accumulated value of 38.90 and a total score of $55.57 \%$ and in the fourth quarter an accumulated value of 45.90 and a total score of $65.57 \%$. Whereas in 2019 in the first quarter there was an accumulated value of 32.30 and a total score of $46.14 \%$, in the second quarter an accumulated value of 36.80 and a total score of $52.57 \%$, in the third quarter an accumulated value of 35.30 and a total score of $50.43 \%$ and in the fourth quarter an accumulated score of 42.90 and a total score of $61.29 \%$.

As for PT. Adhi Karya (Persero) Tbk in early 2020 the health level of PT. Adhi Karya (Persero) Tbk experienced a slower decline than the previous year, and this was due to the impact of the Covid 19 Pandemic, which limited economic activity around the world. In the first to fourth quarters, it shows the predicate Unhealthy with category B. The total accumulated value obtained in 2020 in the first quarter is 23,70 , and the total score is $33.86 \%$, in the second quarter, the accumulated value is 23,20 , and the total score is $33,14 \%$, in the third quarter, the accumulated value was 24,20 , and the total score was $34,57 \%$, and in the fourth quarter the accumulated value was 24,60 , and the total score was $35,14 \%$.

\section{Conclusionand Suggestion}

Based on the results of the research, it can see that the development of the financial performance of the four BUMN companies in the construction sector for the 2016-2020 quarterly period as a whole seen from the accumulated weight of the assessment shows that the company's financial performance has decreased due to the impact of the Covid Pandemic 19, based on the results of the research it is known that the company who can recover or recover properly due to the impact of the Covid 19 Pandemic which hinders economic activity, namely the graph of PT Wijaya Karya (Persero) Tbk which occupies the top position with the trend that is experiencing the best recovery at the time of the Covid 19 Pandemic in 2020 in fourth quarter, then followed by PT. Pembangunan Perumahan (Persero) Tbk, PT. WaskitaKarya (Persero) Tbk, and at the lowest position, namely PT Adhi Karya (Persero) Tbk.

Based on the conclusions that have obtained from the results of the analysis of the financial performance appraisal and the development of the construction sector BUMN companies listed on the Indonesia Stock Exchange for the 2016-2020 quarterly period, the suggestions are as follows:

a. The management systems of the four companies should pay more attention to policies related to financial performance appraisal indicators, which still receive low weighting scores. By paying attention to the policy correctly, it hopes that it can positively improve the indicators of financial performance appraisal to impact the company's financial performance positively.

b. For all state-owned construction companies listed on the Indonesia Stock Exchange for the 2016-2020 quarterly period, the trend graph shows that performance tends to recover from the impact of the Covid 19 pandemic, which weakened economic conditions. It hopes that the four companies can maintain consistency or be better in improving the company's financial performance in the Covid 19 Pandemic.

\section{Reference}

Dewi, M. (2017). Penilaian Kinerja Keuangan Perusahaan dengan Menggunakan Metode EVA (Economic Value Added) (Studi Kasus pada PT. Krakatau Steel Tbk Periode 2012-2016). Jurnal Manajemen Dan Keuangan Unsam, 6(1), 648-659.

Fakih, S. (2019). Analisis Kinerja Keuangan Perusahaan Bumn Bidang Konstruksi Yang Terdaftar Di Bursa Efek Indonesia Periode 2012 - 2016. Equator Journal Of Management and Entrepreneurship, Vol 7, No.1 https://doi.org/http://dx.doi.org/10.26418/ejme.v7i1.27612

Gunawan Ade, Wahyuni, S. F. (2013). Pengaruh Rasio Keuangan Terhadap Pertumbuhan Laba Pada Perusahaan Perdagangan Di Indonesia. Jurnal Ilmiah Manajemen Dan Bisnis, VOL 13 NO.1 https://doi.org/https://doi.org/10.30596/jimb.v13i1.102

Hindrayani, A. (2017). Bank-firm Relationships dan Kinerja Keuangan: Analisis pada Sektor Industri di Indonesia. Jurnal Pendidikan Ekonomi Manajemen Dan Keuangan, Vol. 1 No.1

Indrawati, A. (2017). Analisis Trend Kinerja Keuangan Bank KALTIM. Research Journal of Accounting and Business Management, Vol 1, No.2 https://doi.org/https://doi.org/10.31293/rjabm.v1i2

Maith, H. A. (2013). Analisis Laporan Keuangan Dalam Mengukur Kinerja Keuangan Pada Pt. Hanjaya Mandala Sampoerna Tbk. JURNAL EMBA: JURNAL RISET EKONOMI, MANAJEMEN, BISNIS DAN AKUNTANSI, VOL 1 NO 3. https://doi.org/https://doi.org/10.35794/emba.v1i3.2130

Muryadi, A. D. (2017). Model Evaluasi Program Dalam Penelitian Evaluasi. Jurnal Ilmiah Penjas (Penelitian, Pendidikan Dan Pengajaran), Vol 3 No 1(Vol. 3 No. 1 (2017): Jurnal Ilmiah Penjas). 
http://ejournal.utp.ac.id/index.php/JIP/article/view/538

Nasruddin, R., \& Haq, I. (2020). Pembatasan Sosial Berskala Besar (PSBB) dan Masyarakat Berpenghasilan Rendah. Jurnal Sosial Dan Budaya Syar-I, Vol 7 No 7. https://doi.org/https://doi.org/10.15408/sjsbs.v7i7.15569

Nasution, L. K., \& Sari, S. N. (2016). Penilaian Tingkat Kesehatan Bumn Pada Pt. Waskita Karya (Persero) Tbk. Jurnal Bisnis Administrasi, Vol 5 No 1.

Pradiva, P., Salain, P., Santana, M., Adiyadnya, P., Kangin, D. P., \& Utara, D. (2021). Jurnal Satyagraha Studi Eksplorasi Dampak Work From Home Pada Kinerja Karyawan Bumn Di Wilayah Denpasar Karyawan Di Masa Pandemi Covid-19.03(02), 19-27.

Ristyawati, A. (2020). Efektifitas Kebijakan Pembatasan Sosial Berskala BesarDalam Masa Pandemi Corona Virus 2019oleh Pemerintah Sesuai Amanat UUD NRI Tahun 1945. Administrative Law \& Governance Journal, Vol 3, No.2 https://doi.org/https://doi.org/10.14710/alj.v3i2.240-249

Sanjaya, S., \& Rizky, M. F. (2018). Analisis Profitabilitas Dalam Menilai Kinerja Keuangan Pada PT. Taspen (Persero) Medan. JURNAL AKUNTANSI DAN KEUANGAN SYARIAH, VOL. 2 NO.2 http://jurnal.uinsu.ac.id/index.php/JAKS/issue/view/296

Saputro, F. G. (2015). Analisis Kinerja Keuangan Perusahaan Bumn Bidang Konstruksi Yang Terdaftar Di Bursa Efek Indonesia Periode 2010-2013. Jurnal E-Prints UNY.

Sumiyati, Y. (2013). Peranan BUMN dalam Pelaksanaan Tanggung Jawab Sosial Perusahaan untuk $\begin{array}{lllllll}\text { Meningkatkan Kesejahteraan } & \text { Rakyat. Jurnal Hukum, } & \text { Vol } 3\end{array}$ https://doi.org/https://doi.org/10.20885/iustum.vol20.iss3.art7

Suryantini, A. W. P. N. P. S. (2016). Pengaruh Profitabilitas, Rasio Solvabilitas, Ukuran Perusahaan, Dan Reputasi Auditor Terhadap Peringkat Obligasi Pada Sektor Perbankan. Junral Manajemen Unud, Vol. 5,No.10(6670-6699).

https://ojs.unud.ac.id/index.php/Manajemen/article/download/23748/15760

Susilo, W. (2014). Peran Informasi Akuntansi Sebagai Alat Akuntabilitas Internal, Evaluasi Kinerja Keuangan Dan Pengambilan Keputusan Keuangan Pada Instansi Vertikal Pemerintah Pusat. Accounting and Business Information System Journal, Vol 2 No 2. https://journal.ugm.ac.id/abis/issue/view/4352

Thrisye, R. Y., \& Simu, N. (2013). Analisis Pengaruh Rasio Keuangan Terhadap Return Saham Bumn Sektor Pertambangan Periode 2007-2010. Jurnal Ilmu Akuntansi Dan Bisnis, VOL 8 NO 2. https://doi.org/https://doi.org/10.24843/JIAB.2013.v08.i02

Ulupui, I. G. K. A. (2007). Analisis Pengaruh Rasio Likuiditas, Leverage, Aktivitas, Dan Profitabilitas Terhadap Return Saham (Studi Pada Perusahaan Makanan Dan Minuman Dengan Kategori Industri Barang Konsumsi Di Bej). Jurnal Ilmiah Akuntansi Dan Bisnis, VOL 2 NO 1. https://doi.org/https://doi.org/10.24843/JIAB.2007.v02.i01

Veno, A. (2016). Analisis Trend Kinerja Keuangan Perbankan Syariah Tahun 2015 Sampai Dengan 2017. Jurnal Bisnis Dan Manajemen Islam, Vol 4, No.1 https://doi.org/OI: http://dx.doi.org/10.21043/bisnis.v4i1

Yusra, I. (2016). Kemampuan Rasio Likuiditas Dan Solvabilitas Dalam Memprediksi Laba Perusahaan: Studi Empiris Pada Perusahaan Telekomunikasi Yang Terdaftar Di Bursa Efek Indonesia. Jurnal Benefita, vol1 no $1 . \quad$ https://d1wqtxts1xzle7.cloudfront.net/52004771/878-2475-1PB.pdf?1488509564=\&response-content-

disposition=inline\%3B+filename\%3DKEMAMPUAN_RASIO_LIKUIDITAS_DAN_SOLVABILI.pdf\&Expi res=1600782845\&Signature=KzuNNTmIeh9Nn5zglc2Mhztcgo1ynXYXRN348LIJUGaNb2YFfgaKDm 